University of Nebraska - Lincoln

DigitalCommons@University of Nebraska - Lincoln

6-1992

Cestode Parasites in Potamotrygon motoro (Natterer) (Chondrichthyes: Potamotrygonidae) from Southwestern Brazil, including Rhinebothroides mclennanae n. sp. (Tetraphyllidea: Phyllobothriidae), and a Revised Host-Parasite Checklist for Helminths Inhabiting Neotropical Freshwater Stingrays

\author{
Daniel R. Brooks \\ University of Toronto,dnlbrooks@gmail.com \\ Jose F.R. Amato \\ Universidade Federal Rural do Rio de Janeiro
}

Follow this and additional works at: https://digitalcommons.unl.edu/parasitologyfacpubs

Part of the Parasitology Commons

Brooks, Daniel R. and Amato, Jose F.R., "Cestode Parasites in Potamotrygon motoro (Natterer) (Chondrichthyes: Potamotrygonidae) from Southwestern Brazil, including Rhinebothroides mclennanae $\mathrm{n}$. sp. (Tetraphyllidea: Phyllobothriidae), and a Revised Host-Parasite Checklist for Helminths Inhabiting Neotropical Freshwater Stingrays" (1992). Faculty Publications from the Harold W. Manter Laboratory of Parasitology. 247.

https://digitalcommons.unl.edu/parasitologyfacpubs/247

This Article is brought to you for free and open access by the Parasitology, Harold W. Manter Laboratory of at DigitalCommons@University of Nebraska - Lincoln. It has been accepted for inclusion in Faculty Publications from the Harold W. Manter Laboratory of Parasitology by an authorized administrator of DigitalCommons@University of Nebraska - Lincoln. 


\title{
CESTODE PARASITES IN POTAMOTRYGON MOTORO (NATTERER) (CHONDRICHTHYES: POTAMOTRYGONIDAE) FROM SOUTHWESTERN BRAZIL, INCLUDING RHINEBOTHROIDES MCLENNANAE N. SP. (TETRAPHYLLIDEA: PHYLLOBOTHRIIDAE), AND A REVISED HOST-PARASITE CHECKLIST FOR HELMINTHS INHABITING NEOTROPICAL FRESHWATER STINGRAYS
}

\author{
Daniel R. Brooks and Jose F. R. Amato* \\ Department of Zoology, University of Toronto, Toronto, Ontario, Canada M5S 1A1
}

\begin{abstract}
Specimens of 5 species of cestodes were collected in 6 specimens of the freshwater stingray species Potamotrygon motoro (Natterer), collected in the vicinity of Corumba, Mato Grosso do Sul, Brazil. Acanthobothrium regoi, Potamotrygonocestus orinocoensis, Rhinebothroides venezuelensis, and Rhinebothrium paratrygoni are reported from $P$. motoro and from southwestern Brazil for the first time. Rhinebothroides mclennanae $\mathrm{n}$. sp. appears to be the sister species of Rhinebothroides glandularis, the only other member of the genus exhibiting darkly staining glandular cells lying free in the parenchyma surrounding the terminal genitalia. The new species resembles Rhinebothroides glandularis, Rhinebothroides freitasi, and Rhinebothroides scorzai by having poral ovarian arms that extend anteriorly beyond the posterior margin of the cirrus sac, coiled vaginae, and vitelline follicles not interrupted on the poral side in the vicinity of the genital pore. It differs from all 6 previously described members of the genus by possessing an average of 31 testes per proglottid, compared with an average of 45 for $R$. glandularis, 55 for $R$. freitasi and $R$. venezuelensis, 77 for Rhinebothroides circularisi and Rhinebothroides moralarai, and 80 for $R$. scorzai. An updated phylogenetic tree for Rhinebothroides is presented.
\end{abstract}

Stingrays of the family Potamotrygonidae, permanently restricted to neotropical freshwater habitats, host a rich helminth fauna that strongly reflects their Pacific marine ancestry (Brooks, Thorson, and Mayes, 1981; Brooks and Deardorff, 1988; Brooks and McLennan, 1991). On 29 May 1988, 6 specimens of Potamotrygon motoro (Natterer), collected in the vicinity of Corumba, Mato Grosso do Sul, Brazil, were examined for helminth parasites. Specimens of 5 species of cestodes were collected, 4 of which are reported from $P$. motoro and from the Pantanal region of Brazil for the first time and 1 of which is described herein as a new species.

\section{MATERIALS AND METHODS}

Stingrays were collected with hand-held spears. Cestodes were relaxed in tap water until moribund, then fixed in alcohol-formalin-acetic acid and stored in $70 \%$ ethanol. Whole mounts were stained with Mayer's hematoxylin and mounted in Canada balsam. Serial cross sections of proglottids were cut $5 \mu \mathrm{m}$ thick, stained with hematoxylin-eosin, and mounted in Canada bal-

Received 12 July 1991; revised 30 January 1992; accepted 31 January 1992.

* Instituto de Biologia, Universidade Federal Rural do Rio de Janeiro, km 47 antiga Rodovia Rio-São Paulo, 23851-Seropedica, Rio de Janeiro, Brazil. sam. All measurements are in micrometers. Measurements are based on 25 observations unless noted by " $n$," indicating a higher number of observations as stated in each case.

\section{DESCRIPTION \\ Rhinebothroides mclennanae n. sp. (Figs. 1-4)}

Description (based on examination of 70 specimens): Strobila craspedote, apolytic, up to $25 \mathrm{~mm}$ long, composed of 16-25 proglottids. Scolex with 4 pedicellated, bilobed, elongate bothridia; apical complex lacking. Pedicels contractile, 188-312 long. Bothridia 625-875 long by $281-418$ wide; hingelike constriction between lobes; divided into marginal and medial portions by indistinct marginal septum; divided horizontally by 24-29 septa; medial loculi 49-59 in number; marginal loculi 49-59 in number. Immature proglottids squared to longer than wide. Mature proglottids 938-1,950 long by $294-438$ wide. Testes in 2 broad fields in anterior $2 / 3$ of proglottid, $19-43$ in number $(n=293 ; \bar{x}=31)$; $25-47$ in diameter. Cirrus sac in posterior $20-25 \%$ of proglottid, 218-344 long by 50-70 wide, containing spined eversible cirrus and internal seminal vesicle, poral end surrounded by darkly staining cells lying free in the parenchyma. External seminal vesicle extending length of cirrus sac, with extensive coiling immediately anterior to cirrus sac, joining cirrus sac near poral end and vas deferens near posterior end of proglottid. Genital atrium shallow; genital pores alternating irregularly $22-33 \%(\bar{x}=27 \%)$ of total proglottid length from posterior end. Vagina anterior to cirrus sac, coiled; vaginal 
sphincter and seminal receptacle present. Ovary bilobed in frontal view, $\mathrm{X}$-shaped in cross section; aporal lobe 468-812 long, extending anteriorly to level of posterior extent of testicular field; poral lobe 218-375 long, extending anteriorly to level of cells surrounding pos-
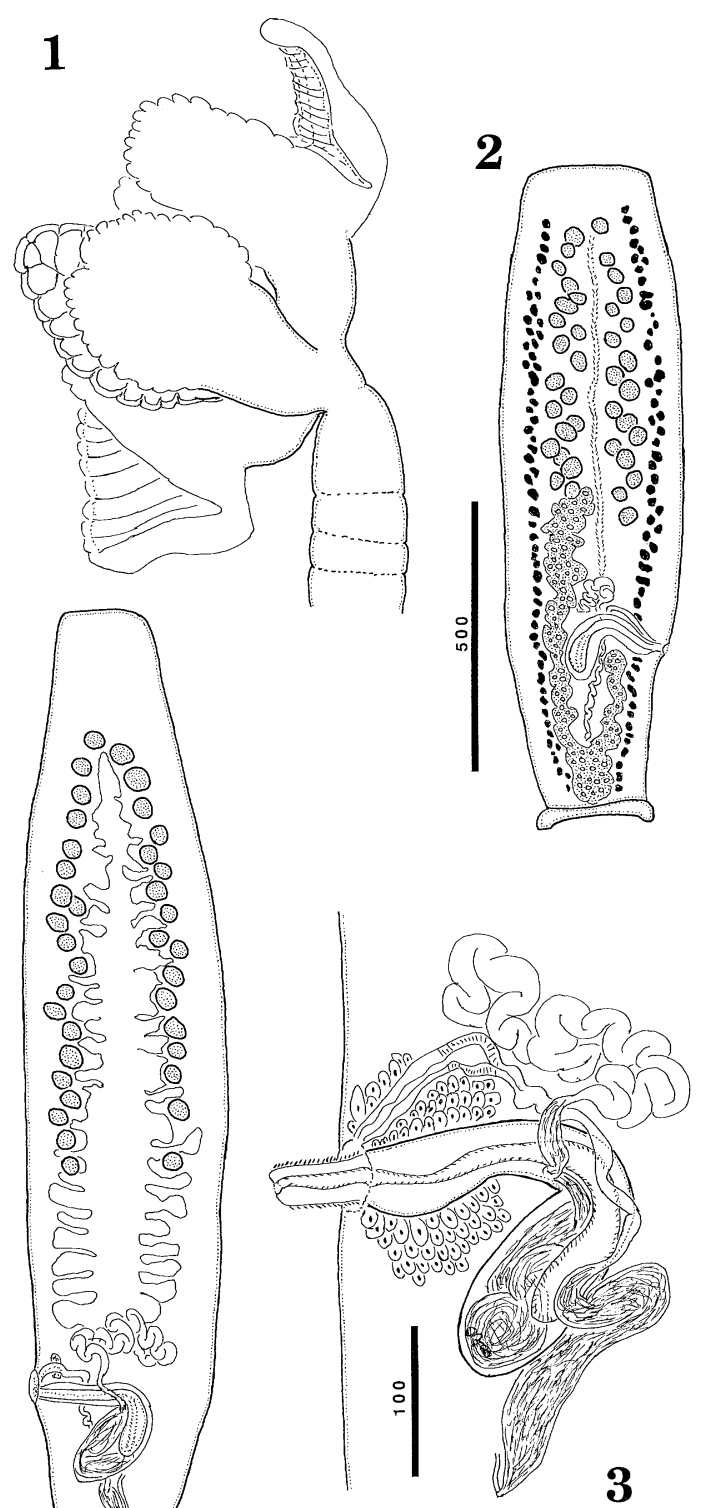

FIGURES 1-4. Rhinebothroides mclennanae n. sp. 1. Scolex. 2. Mature attached proglottid. 3. Terminal genitalia. 4. Gravid attached proglottid. Scale bar indicating $500 \mu \mathrm{m}$ is for Figures 1, 2, 4; scale bar indicating $100 \mu \mathrm{m}$ is for Figure 3. terior of genital pore; $125-188$ wide at isthmus. Vitelline follicles lateral, extending from anterior extent of testicular fields to near posterior end of proglottid, not interrupted near genital pore; 9-25 in diameter. Terminal gravid attached proglottids 1,625-2,218 long by $362-456$ wide, tapered posteriorly with spinose quadrilobed posterior ends; lacking ovaries and with degenerating testes. Genital pore $25-31 \%(\bar{x}=27 \%)$ of proglottid length from posterior end. Uterus saccate with 44-64 ( $\bar{x}=55)$ lateral diverticula. Eggs $15-18$ in diameter, oncospheres 14-17 in diameter, not embryonated in utero.

\section{Taxonomic summary}

Type host: Potamotrygon motoro (Natterer) (Chondrichthyes: Myliobatiformes: Potamotrygonidae).

Type locality: Vicinity of Corumba, Mato Grosso do Sul, Brazil.

Site of infection: Middle third of spiral valve.

Specimens deposited: Holotype: Instituto Oswaldo Cruz no. 32.814a. Paratypes: Instituto Oswaldo Cruz no. 32.814b-f (75 specimens); Harold W. Manter Laboratory, Division of Parasitology, University of Nebraska State Museum no. 34091 (2 specimens).

Etymology: The species is named for Deborah A. McLennan.

\section{Remarks}

Rhinebothroides mclennanae is the seventh species named to this genus of cestodes, all of which are restricted to potamotrygonid stingrays. The new species appears to be the sister species of Rhinebothroides glandularis Brooks, Mayes, and Thorson, 1981, the only other member of the genus exhibiting darkly staining glandular cells lying free in the parenchyma surrounding the terminal genitalia. We are not aware that this feature is found in any other tetraphyllideans and consider it a synapomorphy for $R$. glandularis plus $R$. mclennanae. The new species further resembles $R$. glandularis, Rhinebothroides freitasi (Rego, 1979) Brooks, Mayes, and Thorson, 1981, and Rhinebothroides scorzai (Lopez-Neyra and Diaz-Ungria, 1958) Mayes, Brooks, and Thorson, 1981, and differs from Rhinebothroides moralarai (Brooks and Thorson, 1976) Mayes, Brooks, and Thorson, 1981, Rhinebothroides venezuelensis Brooks, Mayes, and Thorson, 1981, and Rhinebothroides circularisi Mayes, Brooks, and Thorson, 1981 , by having poral ovarian arms that extend anteriorly beyond the posterior margin of the cirrus sac, coiled vaginae, and vitelline follicles not interrupted on the poral side in the vicinity of the genital pore. Rhinebothroides mclennanae differs from all 6 previously described members of the genus by possessing substantially fewer testes per proglottid (an average of 31, with a range of 19-43). Rhinebothroides glandularis averages 45 testes per proglottid, with a range of $41-51, R$. freitasi averages 55 with a range of $48-64, R$. venezuelensis averages 53 with a range of $45-64, R$. circularisi and $R$. moralarai average 77 with a range of $66-88$, and $R$. scorzai averages 80 with a range of 60-99.

Figure 5 depicts a phylogenetic tree for Rhinebothroides species, based on the characters used by Brooks, Mayes, and Thorson (1981) for the same taxa. The new tree differs only in the inclusion of $R$. mclennanae, which is corroborated as the sister species of $R$. glan- 


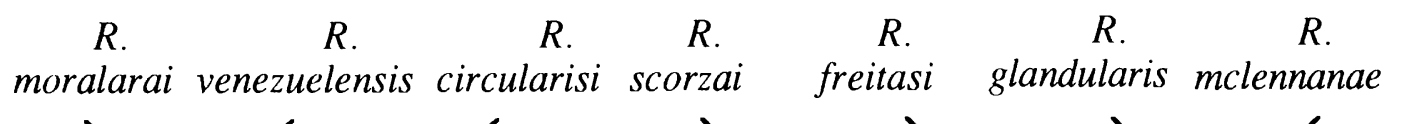
(2)

FIGURE 5. Phylogenetic tree for 7 species of Rhinebothroides. Numbers accompanying slash marks on tree refer to putative synapomorphies as follows: $1-1$, external seminal vesicle joining cirrus sac near poral end; $2-1$, aporal ovarian lobes elongate; $3-1$, vitellaria interrupted near genital pore on pore side; $4-1$, poral ovarian lobe extending anteriorly only to posterior end of cirrus sac; 5-1, vagina coiled; 6-1, darkly staining glandular cells lying free in the parenchyma surrounding the terminal genitalia; 7-0, proglottids acraspedote; 7-1, proglottids craspedote; 8-1, averages of 53-55 testes per proglottid; 8-2, an average of 45 testes per proglottid; 8-3, an average of 31 testes per proglottid; 9-1, 49-59 loculi per bothridium; 9-2, 41-45 loculi per bothridium.

dularis. Outgroup comparisons relied on several levels of outgroups including phyllobothriids having medial and marginal loculi and genitalia located near the ovary (see also Brooks, Mayes, and Thorson, 1981), and general tetraphyllidean and general eucestode traits as suggested by a phylogenetic analysis of the higher level relationships among major eucestode groups (Brooks et al., 1991). Six characters could be polarized unambiguously in this manner as the apomorphic states in binary transformation series: external seminal vesicle joining cirrus sac near poral end (1-1 in Table I and Fig. 5); elongate aporal ovarian lobes (2-1 in Table I and Fig. 5); vitellaria interrupted near genital pore on pore side (3-1 in Table I and Fig. 5); poral ovarian lobe extending anteriorly only to posterior end of cirrus sac (4-1 in Table I and Fig. 5); vagina coiled (5-1 in Table I and Fig. 5); and darkly staining glandular cells lying free in the parenchyma surrounding the terminal genitalia (6-1 in Table I and Fig. 5). Three additional transformation series provided ambiguous information, for which outgroup comparisons were augmented by functional outgroup analysis and phylogenetic optimization (Brooks and McLennan, 1991; Wiley et al., 1991).

First, functional outgroup analysis and optimization of testes number per proglottid (character 8 in Table I and Fig. 5) are consistent with the hypothesis that the plesiomorphic condition in Rhinebothroides is a range of 60-99 testes per proglottid, with averages of 77-80 ( $R$. scorzai has 60-99 testes per proglottid reported for it, whereas $R$. circularisi and $R$. moralarai have 66-88 reported). Four species have derived conditions: $R$. venezuelensis has an average of $53 ; R$. freitasi has an average of $55 ; R$. glandularis has an average of 45 ; and $R$. mclennanae has an average of 31 . Based on character optimization, we consider the conditions exhibited by $R$. venezuelensis and $R$. freitasi to be convergent traits (8-1 in Table I and Fig. 5), the condition exhibited by $R$. glandularis to be derived from that found in $R$. freitasi (8-2 in Table I and Fig. 5), and that found in $R$. mclennanae to be derived from that found in $R$. glandularis (8-3 in Table I and Fig. 5).

Second, the number of medial loculi per bothridium (which is the same as the number of marginal loculi per bothridium in Rhinebothroides) (character 9 in Table I and Fig. 5) also varies greatly among these species, and the structure of the bothridia themselves makes it more difficult to assess loculi number consistently. However, the number of bothridial loculi has been used as an important taxonomic character for other tetraphyllidean groups, such as Rhinebothrium and its relatives, and Echeneibothrium and its relatives. Current reports list $R$. moralarai as having 45-49 medial loculi per bothridium, $R$. venezuelensis as having 51-53 loculi, $R$. circularisi as having 69-79, $R$. scorzai as having $69-79, R$. freitasi as having approximately $59, R$. glan- 
TABLE I. Data matrix summarizing character argumentation for 9 transformation series for 7 species of Rhinebothroides.*

\begin{tabular}{lccccccccc}
\hline & \multicolumn{7}{c}{ Characters } \\
\cline { 2 - 10 } Taxa & 1 & 2 & 3 & 4 & 5 & 6 & 7 & 8 & 9 \\
\hline OG & 0 & 0 & 0 & 0 & 0 & 0 & 0 & 0 & 0 \\
MO & 1 & 1 & 1 & 1 & 0 & 0 & 0 & 0 & 2 \\
VE & 1 & 1 & 1 & 1 & 0 & 0 & 1 & 1 & 1 \\
CI & 1 & 1 & 1 & 1 & 0 & 0 & 0 & 0 & 0 \\
SC & 1 & 1 & 0 & 0 & 1 & 0 & 1 & 0 & 0 \\
FR & 1 & 1 & 0 & 0 & 1 & 0 & 0 & 1 & 1 \\
GL & 1 & 1 & 0 & 0 & 1 & 1 & 1 & 2 & 1 \\
MC & 1 & 1 & 0 & 0 & 1 & 1 & 1 & 3 & 1 \\
\hline
\end{tabular}

* OG, outgroup; MO, R. moralarai; VE, R. venezuelensis; CI, R. circularisi; SC, $R$. scorzai; FR, $R$. freitasi; GL, $R$. glandularis; MC, $R$. mclennanae. 1-0, no external seminal vesicle joining cirrus sac near poral end; $1-1$, external seminal vesicle joining cirrus sac near poral end; $2-0$, aporal ovarian lobes not elongate; $2-1$, aporal ovarian lobes elongate; 3-0, vitellaria not interrupted near genital pore on pore side; $3-1$, vitellaria interrupted near genital pore on pore side; $4-0$, poral ovarian lobe extending anterior to posterior end of cirrus sac; 4-1, poral ovarian lobe extending anteriorly only to posterior end of cirrus sac; $5-0$, vagina not coiled; $5-1$, vagina coiled; $6-0$, no darkly staining glandular cells lying free in the parenchyma surrounding the terminal genitalia; 6-1, darkly staining glandular cells lying free in the parenchyma surrounding the terminal genitalia; $7-0$, proglottids acraspedote; $7-1$, proglottids craspedote; $8-0$, averages of $77-80$ testes per proglottid; $8-1$, averages of 53-55 testes per proglottid; $8-2$, an average of 45 testes per proglottid; $8-3$, an average of 31 testes per proglottid; 9-0, 69-79 loculi per bothridium; 9-1, 49-59 loculi per bothridium; 9-2, 41-45 loculi per bothridium.

dularis as having 51-59, and $R$. mclennanae as having 49-59. If we begin conservatively by recognizing 2 categories of loculi number, 69-79 and 45-59, functional outgroup analysis is consistent with the hypothesis that the plesiomorphic condition is 69-79 medial loculi, because $R$. scorzai and $R$. circularisi are basal members of their respective subclades within Rhinebothroides. Character optimization supports either the hypothesis that 45-59 loculi is the plesiomorphic condition or that $69-79$ is the plesiomorphic condition, because each hypothesis requires convergent evolution of the derived state. We have adopted the hypothesis that 6979 loculi is the plesiomorphic condition, because two criteria (character optimization and functional outgroup analysis) are consistent with it. Using the plesiomorphic condition as a reference point, 2 groups of species exhibit derived conditions for numbers of bothridial loculi. First, the reported values of $R$. freitasi, $R$. glandularis, and $R$. mclennanae fall within 49-59 loculi, and we consider them to have the same state (9-1 in Table I and Fig. 5). Second, there appear to be 2 ways of interpreting the observations that $R$. venezuelensis has 51-53 loculi and $R$. moralarai has 4549 loculi. On one hand, the total range of 45-53 loculi exhibited by the 2 species is not broader, and does not differ substantially from, that exhibited by the $R$. freitasi-R. glandularis-R. mclennanae group; therefore, these 2 species could be considered to exhibit a common trait that is convergent with the condition found in the $R$. freitasi- $R$. glandularis $-R$. mclennanae group. Alternatively, it could be recognized that although the value for $R$. venezuelensis falls within the values re- ported for the $R$. freitasi-R. glandularis- $R$. mclennanae group, the values for $R$. moralarai fall below them. The only difference between the alternatives is the recognition of an autapomorphic trait for $R$. moralarai, so the phylogenetic tree topology is not affected. We have chosen the latter interpretation, which results in the hypothesis that the condition found in $R$. venezuelensis (9-1) is convergent with that found in the $R$. frietasi-R. glandularis- $R$. mclennanae group (9-1) and is plesiomorphic to the condition found in $R$. moralarai (9-2 in Table I and Fig. 5).

Third, proglottids of Rhinebothroides species may be craspedote or acraspedote (character 7 in Table I and Fig. 5). The general plesiomorphic condition among all eucestodes is acraspedote, but the derived condition, craspedote proglottids, appears to be a relatively common and convergent trait. Treating the craspedote condition as apomorphic for Rhinebothroides leads to the postulate that craspedote proglottids have appeared 2 times independently (7-1 in Fig. 5) and have been secondarily lost once (7-0 in Fig. 5).

Table I presents a data matrix summarizing the above character argumentation in a format suitable for computer-assisted analysis. Phylogenetic analysis of this matrix using the PAUP 3.0 computer program (all characters ordered, rooted with an all-zero outgroup function, Acctran or Deltran optimization, Branch and Bound option) produces the tree shown in Figure 5, with a consistency index of $75 \%$.

\section{DISCUSSION}

We collected specimens of 4 other species of cestodes in the $P$. motoro from near Corumba. These included Potamotrygonocestus orinocoensis Brooks, Mayes, and Thorson, 1981, Acanthobothrium regoi Brooks, Mayes, and Thorson, 1981 , and $R$. venezuelensis Brooks, Mayes, and Thorson, 1981, which were known previously only from the delta of the Orinoco River in Venezuela (Brooks, Mayes, and Thorson, 1981) and which had never been collected in P. motoro. In addition, we collected specimens of Rhinebothrium paratrygoni Rego and Dias, 1976, known previously from the delta of the Orinoco River, the Rio Salobra, Mato Grosso, Brazil, and near Hohenau, Paraguay, but never previously collected in P. motoro. Thus, this report constitutes new host and locality records for all 4 species. Voucher specimens of them have been deposited in the collection of the Instituto Oswaldo Cruz (nos. 32.816a-f [P. orinocoensis, 15 specimens], 32.817a-f $[A$. regoi, 20 specimens], 32.818a- $\mathrm{f}[R$. venezuelensis, 78 specimens], and $32.819 \mathrm{a}-\mathrm{f}[R$. paratrygoni, 7 specimens]) and the Harold W. Manter Laboratory, University of Nebraska State Museum (nos. 34094 [P. orinocoensis, 2 specimens], 34093 [A. regoi, 2 specimens], $34092[R$. venezuelensis, 3 specimens], and 34095 [R. paratrygoni, 1 specimen]). 
TABLE II. Host-parasite list for helminths inhabiting neotropical freshwater stingrays, revised according to the taxonomy and nomenclature of Rosa (1985).*

\footnotetext{
Host species

Parasite species

Potamotrygon magdalenae (Valenciennes, 1865)

Potamotrygonocestus magdalenensis Brooks and Thorson, 1976 Acanthobothrium quinonesi Mayes, Brooks, and Thorson, 1978 Rhinebothroides moralarai (Brooks and Thorson, 1976) Mayes, Brooks, and Thorson, 1981

Paravitellotrema overstreeti Brooks, Mayes, and Thorson, 1979

Potamotrygon yepezi Castex and Castello, 1970

Potamotrygonocestus amazonensis Brooks, Mayes, and Thorson, 1981 Acanthobothrium quinonesi Mayes, Brooks, and Thorson, 1978

Rhinebothroides venezuelensis Brooks, Mayes, and Thorson, 1981

Potamotrygon orbignyi (Castelnau, 1855)

Eutetrarhynchus araya (Woodland, 1934) Rego and Dias, 1976
} Potamotrygonocestus amazonensis Mayes, Brooks, and Thorson, 1981 Potamotrygonocestus orinocoensis Brooks, Mayes, and Thorson, 1981 Acanthobothrium regoi Brooks, Mayes, and Thorson, 1981

Rhinebothrium paratrygoni Rego and Dias, 1976

Rhinebothroides venezuelensis Brooks, Mayes, and Thorson, 1981

Rhinebothroides glandularis Brooks, Mayes, and Thorson, 1981

Rhinebothroides scorzai (Lopez-Neyra and Diaz-Ungria, 1958) Mayes,

Brooks, and Thorson, 1981

Echinocephalus daileyi Deardorff, Brooks, and Thorson, 1981

Potamotrygon constellata (Vaillant, 1880)

Potamotrygonocestus amazonensis Mayes, Brooks, and Thorson, 1981 Acanthobothrium amazonensis Mayes, Brooks, and Thorson, 1978 Rhinebothroides circularisi Mayes, Brooks, and Thorson, 1981 Paraheteronchocotyle tsalickisi Mayes, Brooks, and Thorson, 1981 Potamotrygonocotyle amazonensis Mayes, Brooks, and Thorson, 1981 Echinocephalus daileyi Deardorff, Brooks, and Thorson, 1981

Potamotrygon motoro (Natterer, 1841)

Eutetrarhynchus araya (Woodland, 1934) Rego and Dias, 1976 Potamotrygonocestus orinocoensis Brooks, Mayes, and Thorson, 1981 Acanthobothrium regoi Brooks, Mayes, and Thorson, 1981 Acanthobothrium terezae Rego and Dias, 1976

Rhinebothrium paratrygoni Rego and Dias, 1976

Rhinebothroides scorzai (Lopez-Neyra and Diaz-Ungria, 1958) Mayes, Brooks, and Thorson, 198

Rhinebothroides venezuelensis Brooks, Mayes, and Thorson, 1981 Leiperia gracile (Diesing, 1835)

Brevimulticaecum $\mathrm{sp}$

Potamotrygon falkneri Castex and Maciel, 1963

Eutetrarhynchus araya (Woodland, 1934) Rego and Dias, 1976 Rhinebothrium paratrygoni Rego and Dias, 1976

Potamotrygon histrix (Muller and Henle, 1844) (these records may not all refer to $P$. histrix)

Eutetrarhynchus araya (Woodland, 1934) Rego and Dias, 1976 Potamotrygonocestus travassosi Rego, 1979 species inquirenda Rhinebothrium paratrygoni Rego and Dias, 1976

Rhinebothroides freitasi Rego, 1979

Megapriapus ungriai Lopez-Neyra and Diaz-Ungria, 1958

Paratrygon aiereba (Muller and Henle, 1841)

Rhinebothroides scorzai (Lopez-Neyra and Diaz-Ungria, 1958) Mayes, Brooks, and Thorson, 198

Paratrygon sp. (as Elipesurus sp.)

Acanthobothrium terezae Rego and Dias, 1976

Rhinebothrium paratrygoni Rego and Dias, 1976

Rhinebothroides scorzai (Lopez-Neyra and Diaz-Ungria, 1958) Mayes, Brooks, and Thorson, 198
TABLE II. Continued.

Host species
Parasite species

Trygon sp. (this could have been a species of Plesiotrygon, Paratrygon or Potamotrygon)

Eutetrarhynchus araya (Woodland, 1934) Rego and Dias, 1976

* Parasite records are from Woodland (1934), Lopez-Neyra and Diaz Ungria (1958), Brooks and Thorson (1976), Rego and Diaz (1976), Mayes, Brooks. and Thorson (1978, 1981a, 1981b), Brooks, Mayes, and Thorson (1979, 1981), Rego (1979), Brooks, Thorson, and Mayes (1981), and Deardorff et al. (1981).

Brooks, Mayes, and Thorson (1981) suggested that identification of host species for helminths inhabiting neotropical freshwater stingrays was tentative in some cases, due to the confused nomenclature of the potamotrygonids. Because of this, they reported that they had deposited representative specimens of their hosts in the U.S. National Museum of Natural History. Subsequently, Rosa (1985) revised the family, including examination of the specimens deposited by Brooks, Mayes, and Thorson, and clarified many of the nomenclatural problems. According to Rosa's study, all previous records for Potamotrygon histrix and Potamotrygon reticulatus in the delta of the Orinoco River in Venezuela should be assigned to Potamotrygon orbignyi, and all records for Potamotrygon circularis collected near Leticia, Colombia, should be assigned to Potamotrygon constellata. Table II is a new hostparasite checklist for helminths inhabiting potamotrygonids reflecting Rosa's findings.

\section{ACKNOWLEDGMENTS}

We acknowledge financial assistance from the Conselho Nacional de Desenvolvmento Cientifico e Tecnologico of Brasil in the form of a grant to J.F.R.A. to bring D.R.B. and Deborah A. McLennan to Brazil to conduct a workshop and to perform joint fieldwork. Funds for part of this study were provided by operating grant A7696 from the Natural Sciences and Engineering Research Council of Canada to D.R.B. We especially thank the director and staff of the EMBRAPA laboratory in Corumba, Mato Grosso do Sul, who kindly provided laboratory space and technical assistance. We also thank Joao Batista Catto and Marcello Knoff, who acted as field and laboratory assistants. 


\section{LITERATURE CITED}

Brooks, D. R., AND T. L. DEARdorfF. 1988. Rhinebothrium devaneyi $\mathrm{n}$. sp. (Eucestoda: Tetraphyllidea) and Echinocephalus overstreet $i$ Deardorff and Ko, 1983 (Nematoda: Gnathostomatidae) in a thorny back ray, Urogymnus asperrimus, from Enewetak Atoll, with phylogenetic analysis of both species groups. Journal of Parasitology 74: 459465.

, E. P. Hoberg, ANd P. J. Weekes. 1991. Preliminary phylogenetic systematic analysis of the Eucestoda Southwell, 1930 (Platyhelminthes: Cercomeria). Proceedings of the Biological Society of Washington D.C. 104: 661-668.

- M. A. MAYES, AND T. B. Thorson. 1979. Paravitellotrema overstreetisp. n. (Digenea: Hemiuridae) from the Colombian freshwater stingray Potamotrygon magdalenae Dumeril. Proceedings of the Helminthological Society of Washington 46: 52-54.

,-- AND -1981 . Systematic review of cestodes infecting freshwater stingrays (Chondrichthyes: Potamotrygonidae) including four new species from Venezuela. Proceedings of the Helminthological Society of Washington 48: 43-64.

- AND D. A. MCLennan. 1991. Phylogeny, ecology and behavior: A research program in comparative biology. University of Chicago Press, Chicago, 434 p.

- , AND T. B. Thorson. 1976. Two tetraphyllidean cestodes from the freshwater stingray $\mathrm{Po}$ tamotrygon magdalenae Dumeril in Colombia. Journal of Parasitology 62: 943-947.

$\longrightarrow,-$ AND M. A. MAYES. 1981. Freshwater stingrays (Potamotrygonidae) and their helminth parasites: Testing hypotheses of evolution and coevolution. In Advances in cladistics: Proceedings of the First Meeting of the Willi Hennig Society, V. A. Funk and D. R. Brooks (eds.). New York Botanical Garden, New York, p. 147-175.

DEARDORFF, T. L., D. R. BROOKS, AND T. B. THORSON. 1981. Two species of Echinocephalus (Nematoda: Gnathostomidae) from neotropical stingrays. Journal of Parasitology 67: 433-439.
Lopez-Neyra, C. R., and C. Diaz-Ungria. 1958. Cestodes de Venezuela. V. Cestodes de vertebrados Venezolanos (segunda nota). Nova Ciencia 23: $1-41$.

Mayes, M. A., D. R. Brooks, ANd T. B. Thorson. 1978. Two new species of Acanthobothrium (Cestoidea: Tetraphyllidea) from Colombian freshwater stingrays. Journal of Parasitology 64: 838841 .

phyllidean cestodes from the freshwater stingray Potamotrygon circularis (Garman), with proposal of a new genus. Proceedings of the Helminthological Society of Washington 48: 38-42.

- - - AND $-1981 \mathrm{~b}$. Potamotrygonocotyle tsalickisi gen. et sp. n. (Monogenea: Monocotylidae) and Paraheteronchocotyle amazonensis gen. et sp. n. (Monogenea: Hexabothriidae) from Potamotrygon circularis Garman (Chondrichthyes: Potamotrygonidae) in northwestern Brazil. Proceedings of the Biological Society of Washington D.C. 94: 1205-1210.

Rego, A. A. 1979. Contribucao ao conhecimento dos helmintos de raias fluviais Paratrygonidae. Revista Brasileira de Biologia 39: 879-890.

, AND A. P. L. DiAs. 1976. Estudos de cestoides de peixes do Brasil. 3a nota: Cestoides de raias fluviais Paratrygonidae. Revista Brasileira de Biologia 36: 941-956.

RosA, R. S. 1985. A systematic revision of the South American freshwater stingrays (Chondrichthyes: Potamotrygonidae). Unpublished Dissertation. The College of William and Mary in Virginia. Williamsburg, Virginia, $542 \mathrm{p}$.

Wiley, E. O., D. Siegel-Causey, D. R. Brooks, AND V. A. FunK. 1991. The compleat cladist: A primer of phylogenetic procedures. University of Kansas Press, Lawrence, Kansas, 158 p.

Woodland, W. N. F. 1934. Six new cestodes from Amazon fish. Proceedings of the Zoological Society of London 1: 33-44. 